\title{
Tiempo transcurrido y tiempo de cambio
}

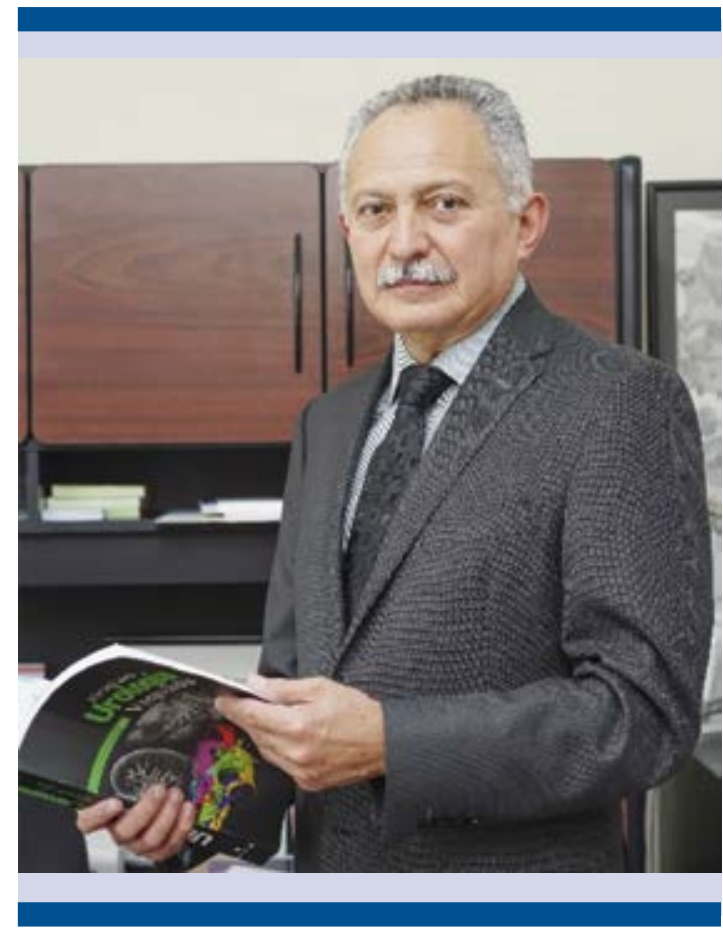

La Revista Mexicana de Urología ha tenido una larga y fructífera vida. Este 2018 cumple 75 años de fundada, seis años después de que un grupo de Urólogos visionarios, encabezados por el Dr. Aquilino Villanueva Arreola, se constituyeran en la Sociedad Mexicana de Urología, marcando desde ese primigenio hito el espíritu y la vocación de la revista, como el órgano oficial de difusión de la Sociedad Mexicana de Urología.
Ese impulso creador tuvo, y tiene en la actualidad, su significación y repercusión, pues de ser un medio de divulgación urológico, se convirtió y se ha ido consolidando como el elemento más importante de publicación científica de la Urología en México.

No fue una labor fácil, este progreso se debió al empeño y dedicación de muchos colegas que han aportado su personal contribución en distintos ámbitos de responsabilidad, para elevar, primordialmente, el nivel de calidad del contenido, a la par de incentivar la presentación de mayor número de trabajos, incluso mejorando su formato, presentación y distribución de manera integral.

El Consejo Directivo actual, que tengo el honor de presidir, tiene un compromiso de calidad y vanguardia con las actividades académicas y científicas, para que la Revista Mexicana de Urología siga alcanzado el máximo nivel en su desempeño y al mismo tiempo sea totalmente accesibla a través de los medios electrónicos y las redes sociales.

De esta forma, la primera edición de Rev Mex Urol 2018 enero-febrero;78 consiste en una presentación completamente digital.

Con esta migración, acorde con nuestro tiempo actual, se obtienen ventajas evidentes como: 
óptima accesibilidad en tiempo y espacio, entrega casi al instante de su producción, no existen ediciones agotadas, lectura y consulta desde cualquier dispositivo electrónico sin ocupar espacio para su almacenamiento y representando ventajas económicas sustanciales en comparación con la producción en papel. Así mismo, permite a los editores publicar más y a los lectores tener títulos adicionales a su disposición.
¡Hoy dimos un paso más en este proceso continuo de evolución de la Revista Mexicana de Urología!

Tiempos de cambio, para mejorar.

Enhorabuena!

Dr. Alfredo Medina Ocampo

DOI: https://doi.org/10.24245/revmexurol.v77i4.2030 